\title{
Maternal and fetal outcome in emergency versus elective caesarean section
}

\author{
Sonal Agrawal ${ }^{1 *}$, Vimal K. Agarwal ${ }^{2}$
}

\begin{abstract}
${ }^{1}$ Department of Obstetrics and Gynecology, Jhalawar Medical College, Jhalawar, Rajasthan, India
${ }^{2}$ Department Of Surgery, Balaji Hospital, Jhalawar, Rajasthan, India
\end{abstract}

Received: 04 November 2018

Accepted: 21 November 2018

\author{
*Correspondence: \\ Dr. Sonal Agrawal, \\ E-mail: drvimal01@gmail.com
}

Copyright: (c) the author(s), publisher and licensee Medip Academy. This is an open-access article distributed under the terms of the Creative Commons Attribution Non-Commercial License, which permits unrestricted non-commercial use, distribution, and reproduction in any medium, provided the original work is properly cited.

\begin{abstract}
Background: Caesarean section preferred as an emergency or elective procedure are entirely different entities according to measures taken, facilities and skilled staff available and preparation done. It has been shown that risk of surgical complications is greater with emergency compared with elective caesarean section.

Methods: Present study is a retrospective study, designed to evaluate maternal and fetal outcomes in elective versus emergency caesarean section performed at our hospital from January 2016 to December 2016.

Results: Out of 2156 caesarean, 1628 were emergency and 528 were elective caesarean section. In our study overall intra operative complications were $11.08 \%$ which was mainly contributed to emergency group.

Conclusions: The elective caesarean section shows less maternal and perinatal complications as compared to emergency caesarean sections. Increasing incidence of emergency caesarean section can be reduced by encouraging all pregnant females to visit antenatal clinics.
\end{abstract}

Keywords: Caesarean section, Fetal outcome, Maternal outcome

\section{INTRODUCTION}

Caesarean section is defined as delivery of fetus, living or dead through an incision on abdominal and uterine wall. The definition does not include removal of fetus from abdominal cavity in case of rupture uterus or abdominal ectopic pregnancy.

Caesarean section has been shown to be a safe operation and in many countries around the world there has been dramatic increase in its frequency. ${ }^{1-4}$ Many vaginal procedure, internal version, destructive operation and symphysiotomy have been things of past. with use of aseptic technique, proper sterilization method, antibiotic therapy, improved anaesthesia and use of blood transfusion, the mortality and morbidity of this surgery have decreased dramatically. In recent years, however use of caesarean section has become increasingly controversial, uncertainty exists about relative risk and benefit of the patient. ${ }^{5}$ The increased rate of caesarean section in present scenario is due to increasing maternal age, reduced parity, breech presentation, extensive use of electronic fetal monitoring. ${ }^{6}$

Present study is a retrospective study, designed to evaluate maternal and fetal outcomes in elective versus emergency caesarean section performed at our hospital.

\section{METHODS}

All obstetric patients undergoing caesarean section (total no. 2156) from January 2016 to December 2016 at SRG Hospital, Jhalawar Medical college, jhalawar were included in study. Maternal data collected included age, parity, mode of previous delivery, whether booked or unbooked case, indication of previous caesarean section, 
intra operative and postoperative complications and duration of hospital stay. Neonatal data includes sex, birth weight, one- and five-minute APGAR score, need for resuscitation, referred to neonatal intensive care unit (NICU), neonatal complications and duration of hospitalization. Case sheets of patients were traced from operation theatre registers. All data were entered in prestructured proforma. Data were analyzed by percentage method.

\section{Inclusion criteria}

- All obstetric patients undergoing caesarean section (total no. 2156) for one year.

\section{Exclusion criteria}

- Patients who underwent normal delivery.

The percentage method was used for analysis.

\section{RESULTS}

During study period 8967 cases were admitted in maternity ward, 2156 underwent caesarean section. The incidence of caesarean section at our hospital comes out to be $24.04 \%$. of these $1628(75.5 \%)$ had emergency and $528(24.5 \%)$ had elective operation. $1681(78 \%)$ were in age group of 20-30 years. The youngest being 18-yearold and eldest was 40-year-old. 1789 (83\%) patients were operated under spinal anaesthesia, out of them 1272 $(71.10 \%)$ underwent emergency caesarean and 517 $(28.89 \%)$ had elective caesarean.

General anaesthesia was given to $36(1.66 \%)$ patients, 33 patient of this group had emergency caesarean and 3 had elective caesarean section. Commonest group delivered by caesarean section was para 1 and 2 i.e. 1724 (80\%). Commonest indication for caesarean section was repeat caesarean $(n=558-25.88 \%)$.

Out of them $358(64.15 \%)$ were operated under emergency circumstances and 200 (35.18\%) were elective caesarean. Fetal distress was found to be cause in $388(17.9 \%$ ) patient, Non-progress of labour in $324(15.20 \%)$, mal presentation in 247 (11.45\%), antepartum haemorrhage in $142(6.58 \%)$ and obstructed labour in $84(3.89 \%)$ patients (Table 1$)$.

Table 1: Indications for caesarean section.

\begin{tabular}{|c|c|c|c|c|c|}
\hline \multirow{2}{*}{ Indications } & \multirow{2}{*}{ Total } & \multicolumn{2}{|l|}{ Emergency } & \multicolumn{2}{|l|}{ Elective } \\
\hline & & No. Of patients & Percentage & No. Of patients & Percentage \\
\hline Repeat caesarean & 558 & 358 & 64.15 & 200 & 35.84 \\
\hline Malpresentation & 247 & 161 & 65.18 & 86 & 34.81 \\
\hline Antepartum haemorrhage & 142 & 101 & 71.12 & 41 & 28.87 \\
\hline Cephalopelvic disproportion & 125 & 98 & 78.4 & 27 & 21.6 \\
\hline Fetal distress & 388 & 388 & 100 & 0 & \\
\hline Preeclampsia & 192 & 120 & 62.5 & 72 & 37.5 \\
\hline Eclampsia & 96 & 96 & 100 & 0 & \\
\hline Obstructed labour & 84 & 84 & 100 & 0 & \\
\hline Non-progress of labour & 324 & 222 & 68.51 & 102 & 31.4 \\
\hline
\end{tabular}

$\mathrm{P}$ fannensteil incision was given in 1510 (70\%) patient, out of these $1132(75 \%)$ patient were in emergency group and $378(25 \%)$ patient were in elective group. 482 cases belonging to emergency group and 164 cases belonging to elective group received midline incision.

Midline incision was mainly given due to presence of previous midline scar. Intra operative complications were seen in 239 patients $(11.08 \%)$.

Out of these $196(82 \%)$ were operated as emergency cases and 43(17.99\%) were operated as elective caesarean.

Among the complications postpartum haemorrhage was most common problem and was encountered in 135 out of 239 cases. 108 of these cases were in emergency group (Table 2).

Wound infection was most common postoperative complication that was seen in 298 cases. Out of these 281 cases were in emergency group.

Table 2: Intra operative maternal complications.

\begin{tabular}{|llll|}
\hline Complications & Total & Emergency & Elective \\
\hline Haemorrhage & 135 & 108 & 27 \\
\hline $\begin{array}{l}\text { Extension of uterine } \\
\text { incision }\end{array}$ & 94 & 79 & 15 \\
\hline $\begin{array}{l}\text { Bladder injury } \\
\begin{array}{l}\text { Caesarean } \\
\text { hystrectomy }\end{array}\end{array}$ & 5 & 4 & 1 \\
\hline
\end{tabular}


Other complications were urinary tract infection, spinal headache. Caesarean hystrectomy was performed in 5 patients due to massive haemorrhage and uterine atony. There were total 3 maternal death (Table 3 ).

Table 3: Postoperative maternal complications.

\begin{tabular}{|llll} 
Complications & Total & Emergency & Elective \\
Wound infection & 298 & 281 & 17 \\
\hline Fever & 162 & 116 & 46 \\
\hline Urinary tract infection & 130 & 98 & 32 \\
\hline Spinal headache & 21 & 12 & 9 \\
\hline DIC & 11 & 10 & 1 \\
\hline Maternal death & 3 & 3 & 0 \\
\hline
\end{tabular}

Out of 2156 babies, $2102(97.40 \%)$ were born alive, of these $1575(73.05 \%)$ were of emergency group and 527 $(24.44 \%)$ were in elective group. 2 babies in emergency group and 1 baby in elective group was still birth. 51 dead babies were delivered by emergency caesarean section. There were total 74 perinatal death. Perinatal mortality was $4.50 \%$ in emergency group and $0.56 \%$ in elective group.

\section{DISCUSSION}

In the last decades, all over the world an increasing trend for caesarean section has been noted..$^{2-4}$ The incidence of caesarean section in our hospital during study period is $24.04 \%$. Out of them $75.5 \%$ were emergency caesarean section and $24.5 \%$ were elective caesarean section. This rate is quite comparable to rate in western countries but does not reflect true caesarean section in given population. Our hospital being a tertiary referral centre receives complicated cases of catchment area.

Mc Carthy FP et al conducted a study in 2005 and reported caesarean section rate of $28.3 \%$ which is quite comparable to our study. In their study most, common indication for caesarean section was previous caesarean. ${ }^{7}$

In a study by Ali et al in 2005 repeat caesarean was most common reason for caesarean section $(43.24 \%)$. In our study common indication were same in elective group but in emergency group the commonest reason for caesarean was repeat caesarean $(25.88 \%)$ followed by fetal distress, non-progress of labour, malpresentation, antepartum haemorrhage, obstructed labour. ${ }^{8}$ Maternal intra operative and postoperative complications were more common in emergency cases as compared to elective ones. In our study overall intra operative complications were $11.08 \%$ which was mainly contributed to emergency group. In a study by Nelison et al incidence of intra operative maternal complications was $11.6 \%$ which is comparable to our study. ${ }^{9}$

Among the intra operative complications massive haemorrhage was most common complication. In our study the incidence of postoperative complication was $13.82 \%$ which was mainly seen in emergency group. The commonest complication encountered was wound infection. In a study by AL Mulhim et al more complications were encountered in cases who underwent emergency caesarean section, with fever being the commonest post-operative complication. ${ }^{10}$

Overall fetal mortality and morbidity were higher in emergency group. Fetal morbidity was $10.50 \%$ of this $85.38 \%$ cases were contributed by emergency group and $14.61 \%$ by elective group. The fetal demise was more in emergency group (Table 4).

Table 4: Fetal complications observed during study.

\begin{tabular}{|llll|}
\hline Complications & Total & Emergency & Elective \\
\hline Respiratory distress & 123 & 102 & 21 \\
\hline Meconium aspiration & 19 & 16 & 3 \\
\hline Sepsis & 29 & 28 & 1 \\
\hline Perinatal death & 74 & 71 & 3 \\
\hline
\end{tabular}

In a study by Ben Onankpa et al in 2009 the perinatal mortality was $11.11 \%$ among caeserean section, the main cause of death was severe birth asphyxia following prolonged obstructed labour. ${ }^{11}$

The conditions associated with poor fetal outcome in our study were prolonged obstructed labour, hypertensive disorders of pregnancy and cephalopelvic disproportion. The major cause of fetal morbidity was severe birth asphyxia, seen mainly in emergency group (Table 5).

Table 5: Fetal outcome.

\begin{tabular}{|lll|}
\hline Outcome & Emergency & Elective \\
\hline Born alive & 1575 & 527 \\
\hline Fresh stillbirth & 2 & 1 \\
\hline Macerated dead baby & 51 & 0 \\
\hline Early neonatal death & 69 & 2 \\
\hline
\end{tabular}

Babies born out of elective caesarean section had less frequent asphyxia and resuscitation than the babies of emergency group. Other studies have also reported similar facts.

\section{Funding: No funding sources \\ Conflict of interest: None declared}

Ethical approval: The study was approved by the Institutional Ethics Committee

\section{REFERENCES}

1. Notzon FC, Cnattingius S, Bergsjø P, Cole S, Taffel $\mathrm{S}$, Irgens $\mathrm{L}$, et al. Cesarean section delivery in the 1980's: International comparison by indication. Am J Obstet Gynecol. 1994;170(2):495-504.

2. Landon MB, Hauth JC, Leveno KJ, Spong CY, Leindecker S, Varner MW et al. Maternal and perinatal outcome associated with trial of labour after 
prior caesarean delivery. $\mathrm{N}$ Eng J. Med, 2005;352(25):1718-20.

3. Gabert HA, Bey M. History and development of cesarean operation. Obstet Gynecol Clinic North Am. 1988;15(4):591-605.

4. Amirikia H, Zarewych B, Evans TN. Cesarean section: A 15-year review of changing incidence, indications, and risks. Am J Obstet Gynecol. 1981;140(1):81-90.

5. Chamberlain G. What is the correct caesarean section rate? BJOG: Int J Obstet Gynaecol. 1993;100(5):403-4.

6. Adashek JA, Peaceman AM, Lopez-Zeno JA, Minogue JP, Socol ML. Factors contributing to the increased cesarean birth rate in older parturient women. Am J Obstet Gynecol. 1993;169(4):936-40.

7. McCARTHY FP, Rigg L, Cady L, Cullinane F. A new way of looking at Caesarean section births. Aus NZ J Obstet Gynaecol. 2007;47(4):316-20.

8. Ali M, Hafeez R, Ahmad M. Maternal and fetal outcome; comparison between emergency caesarean section versus elective caesarean section. Profes 2005;12(1):32-9.

9. Nelson KB, Dambrosia JM, Ting TY, Grether JK. Uncertain value of electronic fetal monitoring in predicting cerebral palsy. New Eng J Med. 1996;334(10):613-9.

10. Mulhim AA, Ali MHA, Abu-Heija TA, Bahnasy A. Factors affecting the rate and the indications of primary caesarean section. Bahrain Medical Bulletin 2001;23(4):160-62.

11. Onankpa B, Ekele B. Fetal outcome following caesarean section in a university teaching hospital. J Natl Med assoc.2009;101(6):578-81.

12. Gasparovic EV, Pulanic KT, Peter B. Maternal and fetal outcome in elective versus emergency section in a developing country. Coll Antropol.2006;30(1):11318.

13. Gaym A. Perinatal mortality audit at Jimma hospital, south western Ethiopia. Ethiop. J Health Dev. 2001;14(3):335-43.

Cite this article as: Agrawal S, Agarwal VK. Maternal and fetal outcome in emergency versus elective caesarean section. Int J Reprod Contracept Obstet Gynecol 2018;7:4845-8. 